\title{
COMMENTS
}

\section{PURCHASES OF CORPORATE INDEBTEDNESS BY A FIDUCIARY}

$\mathrm{O}_{\text {FFICERS and directors of corporations often purchase claims against }}$ their companies for less than face value. There are good reasons for encouraging such purchases: they may be made in order to save the corporation from bankruptcy, or they may increase the incentive of management to have the corporation prosper. There are, nevertheless, some imposing countervailing considerations: the director or officer may have usurped a corporate opportunity when he purchased the obligation, or, if the director or officer thus becomes a creditor of the corporation, there is a potential conflict of interest-under certain circumstances his interest as a creditor may be the antithesis of his duty as an officer or director. Without doubt he can always enforce the claims for an amount equal to cost plus interest. ${ }^{1}$ Under what circumstances courts will attempt to discourage the purchase of corporate claims by allowing the director or officer to enforce the claims for only cost plus interest is unsettled. The need for a definitive statement of the law has long been recognized, ${ }^{2}$ but the officer or director who must decide whether to purchase a claim against his company at a discount finds only the opacity of confusion when he looks to the law.

\section{The Conceptualistic Problem}

The reason for this unsettled state of the law is that the courts have used deductive logic in seeking to solve a problem of values. There is general agreement that a director or an officer of a corporation stands in a fiduciary relation to the corporation and its stockholders. ${ }^{3}$ There is general disagreement, however, over the scope of his fiduciary duty. Four cases in which corporate officials purchased claims against their

\footnotetext{
${ }^{2} 3$ Fletrcher, Private Corporations i 82 n.42 (perm. ed. I93i).

$\Rightarrow$ " $[\mathrm{I}] f$ directors cannot . . . invest in the bonds of their own companies, except at the peril of a constructive fraud; if they cannot safely buy such bonds below par, because they deem them unduly depressed; if titles to corporate obligations, passing through their hands, become tainted by their touches-it is quite time that the courts should give (what they have not given) a very definite and distinct warning." Seymour v. Spring Forest Cemetery Ass'n, r44 N.Y. 333, 342, 39 N.E. 365, 366 (1895).

${ }^{3}$ Horner v. New South Qilmill, 130 Ark. 551, 197 S.W. 1163 (1917); 3 FleTCHER, op. cit. supra note $\mathrm{I}, \S 8_{3} 8$.
} 
corporations show how different conceptions of the fiduciary duty can yield varying results.

The New York Supreme Court, in Inglehart v. Thousand Island Hotel Co., ${ }^{4}$ stated that the fiduciary owes the corporation no duty to purchase claims against it that are selling at a discount. By adopting this very restricted postulation of the fiduciary duty the court concluded that a director or officer could buy claims against the corporation and enforce them at face value unless there was evidence of actual misconduct: ${ }^{5}$

So also a trustee or director may, with his own money, purchase for himself of a third person, a valid and subsisting outstanding debt owing by the company, and secure a perfect title thereto. Such a transaction is not even the ground for entertaining the suspicion that it is in violation of any duty which he owes the corporation, and there is no presumption of law against its fairness.

Seymour v. Spring Forest Cemetery Ass $n^{6}$ took an amplified view of the fiduciary duty: ${ }^{7}$

Unless some special fund has been provided, or some special liquidation has been ordered, the director owes no duty to his company to discharge or buy in the outstanding bonds, and may purchase for himself, because no inconsistent trust duty has arisen.

This case, then, reached a different conclusion from that in the Inglehart case and allowed the director to enforce his claims at face value, unless he bought them for himself when his corporation was also seeking to purchase them.

The Supreme Court of Minnesota, in Hart v. Bell, ${ }^{8}$ took the position that any duty of self-restraint as regards an official's purchasing claims against his corporation lasts only so long as the company is able to purchase the claims: ${ }^{9}$

An officer or director is under a fiduciary obligation to exercise his powers solely for the benefit of the corporation and its stockholders so as not to divert a "corporate" business opportunity to his own use and benefit. Where the opportunity is not "corporate," but "personal," such opportunity belongs

\footnotetext{
32 Hun 377 (N.Y. Sup. Ct. 1884).

Id. at 382 .

144 N.Y. 333,39 N.E. 365 (1895).

${ }^{7} I d$. at 344,39 N.E. at 367 .

8222 Minn. 69, 23 N.W.2d 375 (1946).

${ }^{\circ}$ Id. at $8 \mathrm{I}, 23$ N.W.2d at 382 .
} 
to the officer, and he may treat it as his own. ... [A] business opportunity ceases to be a "corporate opportunity" and becomes "personal" when the corporation is definitely no longer able to avail itself of the opportunity.

The court deduced from this view of fiduciary duty that, if the corporation is not a going concern, the director or officer may enforce discount claims for their face value.

One of the most recent decisions on this subject reached a different result from the previously discussed cases by ostensibly "logical" analysis. The Pennsylvania Supreme Court in Weissman v. A. Weissman, Inc. ${ }^{10}$ held that the fiduciary can enforce claims against his corporation only for cost plus interest if the corporation was solvent when the claims were purchased. This determination was reached by postulating that a fiduciary must not take a corporate advantage for himself. The court concluded that "obviously, it is of advantage to any company to be able to purchase at a discount a liened debt against its property."11

The inconsistent holdings of these courts are not the only results that can be reached by hypothesizing on the fiduciary duty of a corporate officer to his corporation. The trustee of an express or implied trust occupies a fiduciary relationship to the beneficiary ${ }^{12}$ analogous to that which the corporate director owes to his company. The trustee's duty, however, is different from that postulated in the cases mentioned above: $:^{13}$

If the fiduciary buys up for himself such adverse or competing interest in the same property in which his trust exists, he must hold it subject to the trust, if the cestui so demands and tenders the price which the trustee has paid.

Since deductive or definitional reasoning has given no definitive answer to the question under what circumstances an officer or director may enforce claims against his corporation for their face value, perhaps an answer may be reached inductively by analyzing some of the factors that were determinative of the decisions in a few leading cases.

\section{Determinative Factors}

In Wabunga Land Co. v. Schrvanbeck, ${ }^{14}$ a solvent land company owned certain parcels of real estate which another company was sub-

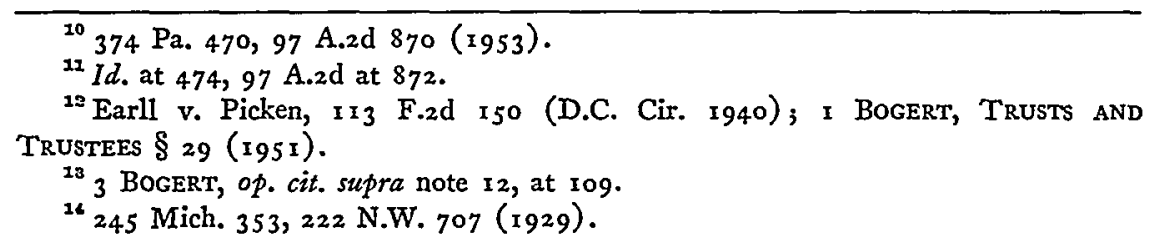


dividing and selling for it on a commission basis. The land company was indebted to the selling company for commissions that had been earned but were not immediately payable. The selling company went into bankruptcy. The trustee in bankruptcy was anxious to receive cash for the claim against the land company that would come due in the future. One of the stockholder-directors of the land company bought this claim for less than face value.

In a suit by the other stockholders against the director for an accounting the trial court made these findings of fact that influenced the Michigan Supreme Court's decision: (I) both the land and the selling companies were owned by one family of which all parties to the action were members; (2) the defendant-director had told his brothers that the only way the land company could purchase the claim at a discount was to use bribery-an untrue statement; (3) it would have been advantageous to the land company to have purchased the claim at a discount, and it had the cash or credit to purchase the account without endangering its financial position. The court held that the defendant-director was a constructive trustee of the contract claim; he could, therefore, enforce the claim for only the amount paid plus interest.

The fact that the corporation is closely or family owned plays an unmentioned role in the determination of the equities of the problem..$^{15}$ The policy reasons for this are obvious. Because the financial position of small companies may change rapidly, and because claims against such companies are not frequently traded in a securities market that would reflect these changes, a significant opportunity to take advantage of the owners of the claims is presented. Furthermore, as a general rule, the policies of a small company are greatly influenced by one or two persons. If they had interests that conflicted with the company's interest, their influence would not be offset by other disinterested officers and directors. The shareholders and directors of a family corporation, moreover, may have a greater tendency to trust each other; this is true even when facts are disclosed that would give the disinterested officers and directors of a large corporation reasonable notice of doubledealing. Our first conclusion, therefore, is that the courts will limit the directors or officers of the close or family corporation to the amount they expended in purchasing the claims. The corollary of this is that

\footnotetext{
${ }^{25}$ See In re Norcor Mfg. Co., 109 F.2d 407 (7th Cir. 1940); Weissman v. A. Weissman, Inc., 374 Pa. 470, 97 A.2d 870 (1953); Thompson v. Mitchell, 128 Wash. 192, 222 Pac. 617 (1924). But see McIntyre v. Ajax Min. Co., 28 Utah 162, 77 Pac. 613 (1904).
} 
the officials of a large corporation with professional management will not be so restricted in their purchase of corporate claims. ${ }^{16}$

Another significant aspect of the case was that the defendant had falsely told his brothers that chicanery would be necessary to secure the outstanding claims at a discount for the corporation. This borders. on fraudulent representation, which understandably influenced the court's decision. Other cases, however, have turned on a less flagrant abuse of an inside position. Mere nondisclosure of the opportunity to. purchase a claim at a discount may be a key consideration. ${ }^{17}$ On the other hand, full disclosure of the opportunity to the other directors and officers, unless they too are attempting to secure the claim for themselves, ${ }^{18}$ will be favorable to the claimant's case. ${ }^{19}$

A third consideration in the Wabringa case was that it would have been advantageous to the corporation to have purchased the outstanding claims. Not only would the purchase have been desirable, but the company could have purchased the claims without endangering its financial position. Of course, a finding that the company was actively

\footnotetext{
10 "In these times a large proportion of the mercantile, commercial and manufacturing business of the country is carried on by corporations, and many of them issue, in large amounts, securities in the form of negotiable instruments, payable in the future, which are purchased and held as investments by capitalists and others, and it has never been questioned but that a director in a corporation of this character might purchase the same of a third person at a discount, and collect from the company the entire sum secured thereby." Inglehart v. Thousand Island Hotel Co., 32 Hun 377 (N.Y. Sup. Ct. 1884). See Hauben v. Morris, 255 App. Div. 35, 5 N.Y.S.2d 721 (1938), $a f^{\prime} d, 281$ N.Y. 652, 22 N.E.2d 482 (1939).

${ }^{17}$ See In re The Van Sweringen Co., 119 F.2d 231 (6th Cir.), cert. denied, 314 U.S. 67I (I94I); Young v. Columbia Land \& Investment Co., 53 Ore. 438, 99 Pac. 936, rehearing denied, 53 Ore. 438, Iог Pac. 212 (1909). But see Horner v. New South Oilmill, 130 Ark. 551, I97 S.W. 1163 (1917). In that case an officer's wifeand another person started a partnership to purchase the depressed claims of the officer's company. The officer acted as an agent for the partnersbip in purchasing the claims and did not disclose this fact to the other officers and directors of his company. The court, conceding that there was an abuse of the position of trust, nevertheless, allowed the partnership the face value of the claims. The only basis for this untenable decision. was that the officer was not purchasing for himself but as an agent for the partnership. In Glenwood Mfg. Co. v. Syme, rog Wis. 355, 85 N.W. 432 (Igor), the presidentdirector of a financially embarrassed company bought the company's discount claims in the name of a dummy. Even though he did not disclose his manipulations a suit to have him declared a constructive trustee of the claims was dismissed.

${ }^{18}$ If the majority of the board of directors and the management are all participants: in the purchase, any disclosure would be inefficacious. All interested directors should, therefore, be restricted to the amount they expended in the purchase of the claims. Mothershead v. Douglas, 2I5 Ark. 519, 22 I S.W.2d 424 (1949).

${ }^{19}$ See Hart v. Bell, 222 Minn. 69, 23 N.W.2d 375 (1946).
} 
in the market for such claims would tend to limit the claimant's recovery. ${ }^{20}$ One case, In re McCrory Stores Corp. ${ }^{21}$ turned upon the fact that the company was actively settling claims against it-even though it was insolvent, but not technically bankrupt, at the time the director purchased the claims. The significant factor, then, is whether the management, using good business judgment, has placed the company in the market for its claims, or, if not, whether it would have been advantageous for the company to be in the market. ${ }^{22}$ Whether the company was able successfully to purchase these claims apparently is not crucial.

A second illustrative case is Alexandrine Hotel Co. v. Whaling, ${ }^{23}$ in which the management of a hotel bought most of the corporation's outstanding bonds for about fifty per cent of their face value during the depression of the 1930's. At the time of this purchase the corporation was technically solvent, but was suffering severe losses. It had no sinking fund set aside for bond payments and had never shown any interest in purchasing these bonds. The management, however, had done the best it could in light of the prevailing economic chaos. The court took judicial notice of the fact that the depression had forced down security values and that outsiders were buying up corporate bonds for a mere fraction of their face value and then cutting out the rights of other security holders. ${ }^{24}$

In a derivative suit to appoint a receiver, management was allowed the full face value of claims submitted. The court laid great stress upon the finding that the claims had been bought for the purpose of saving the corporation and not for using the claims for speculation. ${ }^{25}$ The fact that the management had never attempted to enforce the claims was evidence tending to show the management's purpose.

Whether the fiduciary purchased the claim to speculate on its value or to save the company may be difficult to determine, but the validity

${ }^{20}$ See Horner v. New South Oilmill, r3o Ark. 551, x97 S.W. $1 \times 63$ (1917) discussed at note 17 supra; Weissman v. A. Weissman, Inc., 374 Pa. 470,97 A.2d 870 (1953).

${ }_{21}$ I2 F. Supp. 267 (S.D.N.Y. 1935).

${ }^{32}$ Weissman v. A. Weissman, Inc., 374 Pa. 470, 97 A.2d 870 (1953) (dictum). See Ripperger v. Allyn, 25 F. Supp. 554 (S.D.N.Y. 1938); Young v. Columbia Land \& Investment Co., 53 Ore. 438, 99 Pac. 936, rehearing denied, 53 Ore. 438, ro r Pac. ir 2 (1909).

${ }_{23}^{313}$ Mich. 15, 20 N.W.2d 793 (1945).

${ }^{24} I d$. at 22, 20 N.W.2d 795 .

${ }^{25} \mathrm{Id}$. at $30,20 \mathrm{~N} . W .2 \mathrm{~d} 798$. 
of this criterion is obvious. ${ }^{26}$ There is a great danger that an insider who buys company claims for speculative or investment purposes may be tempted to use his knowledge and position to enhance their value at the expense of other creditors and stockholders. A positive policy reason for this criterion is that it is undesirable to discourage the efforts of a director who is willing to risk his personal finances in order to save his company.

In re Philadelphia \& $W . R y .^{2 \pi}$ considered the effect of bankruptcy on the enforcement of claims purchased at less than their face value. In that case the debtor corporation had been officially bankrupt for ten years. The court, instead of appointing a trustee in bankruptcy, had retained the management in control of the business. During this tenyear period the directors and their relatives had purchased the corporation's bonds at a discount. Some of the bonds had subsequently been resold at a profit, but others were still in the directors' possession. The court in this case allowed the directors to enforce the bonds they retained at the price they had paid for them less any profit they had made on those they had sold. Bankruptcy made it clear that the directors' only reason for purchasing the claims was speculation-certainly it would have been ludicrous to argue that the motive was to save the corporation. The court articulated this underlying policy consideration: $:^{28}$ "The conduct forbidden is the purchase of the bonds of the debtor in order to realize a profit." It is apparent that, even though a director of a going concern and a director of a bankrupt company are both labeled fiduciaries, the duties of the latter demand a more complete disinterestedness. One who is placed by a court in the position of trying to salvage something from the company's assets for creditors should not be allowed to place himself in a position where there is the slightest chance of conflicting self-interest.

In Manufacturers Trust Co. v. Becker ${ }^{29}$ an apartment house corporation had outstanding both a mortgage on its only asset, the building, and some debentures. The corporation was in default on the mortgage

\footnotetext{
${ }^{20}$ Solimine v. Hollander, 128 N.J. Eq. 228, I6 A.2d 203 (1940). See Bradly v. Marine \& R. Phosphate Min. \& Mfg. Co., 3 Fed. Cas. II72 (No. I789) (C.C.S.C. I879); Punch v. Hippolite Co., 340 Mo. 53, roo S.W.2d 878 (1936). But see Lewin v. New York Ambassador, Inc., 6r N.Y.S.2d 492 (Sup. Ct. 1946), aff'd, $27 \mathrm{I}$ App. Div. 927, 67 N.Y.S.2d 706, appeal derried, 27 I App. Div. roo9, 69 N.Y.S.2d 905 (1947).

${ }^{27} 64$ F. Supp. 738 (E.D. Pa. 1946).

${ }^{28}$ In re Philadelphia \& W. Ry., supra note 27 , at 740 .

${ }_{33}^{20} 8$ U.S. 304, affirming 173 F.2d 944 (2d Cir. 1949).
} 
interest payments when its directors submitted to the shareholders an outsider's offer to purchase the property. If the offer had been accepted the debenture holders would have received only five per cent of the value of their claims. Becker, a shareholder, successfully opposed the acceptance of the offer and in turn offered to secure a second mortgage on the property if he and his brother were placed on the board of directors. This proposition was accepted. Even though any shareholder or debenture holder could have participated, the second mortgage was secured through Becker's mother and wife. There was never any threat of foreclosure of the second mortgage although interest was never paid on it. While the company was thus insolvent, but not yet in bankruptcy, Becker's mother and wife purchased the debentures through Becker, mostly from security dealers, at a very large discount. During this period there had been inquiries about the sale price of the building by outsiders; but no firm offer to buy it had been made. Later, when the building was sold, the corporation filed for an arrangement under the Bankruptcy Act. At that time it was determined that the company could have paid a dividend of more than forty-three per cent to debenture holders. Upon these facts a federal district court held that the objection of the indenture trustee to the allowance of the claims owned by Becker's family should be dismissed-that is, Becker's relatives could share pro tanto the face value of the debentures. The Court of Appeals for the Second Circuit affirmed, although there was a vigorous dissent by Judge Hand. ${ }^{30}$ The Supreme Court also affirmed with a dissent. The majority opinions in both the Court of Appeals and the Supreme Court laid great stress upon a finding that the defendants had no information not equally available to the brokers who sold the debentures, ${ }^{31}$ apparently concluding there was no actual bad faith dealing by Becker or his relatives. The argument was made that, because of the insolvency, there arose a conflict of interest. ${ }^{32}$ The interested director was in a position to set the time when a petition in bankruptcy would be filed-a time most advantageous to himself, but not necessarily advantageous to other creditors. The majority opinion of the Supreme Court countered this argument by emphasizing the advantages to be gained from an interested director. ${ }^{33}$ The majority admitted that the closer a company comes to bankruptcy the greater becomes the chance

\footnotetext{
${ }^{30}{ }_{173}$ F.2d at 951.

${ }^{31} I d$. at $949 ; 33^{8}$ U.S. at 309 .

${ }^{33} \mathrm{Id}$. at $3 \mathrm{I} 2$.

${ }^{33} I d$. at 313 .
} 
of conflicting interests; however, they did not indicate any point beyond which the conflict becomes so great that the director will become a constructive trustee of the claim.

The dissenters adopted the rationale of Judge Hand, ${ }^{34}$ arguing that once the company becomes insolvent the potential conflict of interest becomes so great that it outweighs any supposed advantages. Hand believed that, unless the interested director could show that he thought both that the business would keep going through a composition of debts, and that there was good reason to think so, the director should be limited to what he paid for the claims. ${ }^{35}$ In the absence of such evidence, the policy reason for encouraging the director's purchase-that he bought the claims to save the company-is gone. The dissenters in the Supreme Court went so far as to say that the line should not be drawn at technical insolvency, rather stating that "any evidence of the financial instability of the corporation obligates the directors to overcome whatever presumption of conflict of interests between their own and those of the corporation or of its creditors that such evidence presents."365

Great potential conflict of interest and lack of cogent countervailing policy reasons have lead other courts to allow the fiduciary-directors only the amount expended in purchasing claims if they were purchased when the company was insolvent. ${ }^{37}$ Presently, in claims brought in the federal courts, however, absent fraud, bad faith, or actual conflict of interest, mere technical insolvency at the time of the purchase of the claims makes no difference as to enforcement of the claim.

\section{SUMmaRY}

In trying to determine under what conditions a director or officer may purchase outstanding claims against his corporation at a discount

${ }^{34} I d$. at 317 .

35 173 F.2d at 952 .

${ }^{30} 338$ U.S. at 317 .

${ }^{37}$ Prior to the Manufacturers Trust Co. decision the lower federal courts, in bankruptcy proceedings, had restricted the recovery of the directors who purchased their company's claims when it was insolvent. In re The Van Sweringen Co., Irg F.2d 23 I (6th Cir.), cert. denied, $3 \mathrm{r}_{4}$ U.S. $6 \mathrm{I}_{7}$ (1941) ; In re Los Angeles Lumber Products Co., 46 F. Supp. 77 (S.D. Cal. 1941) ; In re McCrory Stores Co., I 2 F. Supp. 267 (S.D.N.Y. I935).

Manufacturers Trust Co. has not altered the restrictive policy followed by some state courts when a director or officer purchases his company's claims at a discount while the company is insolvent. Mothershead v. Douglas, 215 Ark. 519, 221 S.W.2d 414 (r949); Horner v. New South Oilmill, 30 Ark. 551, 197 S.W. II63 (1917) (dictum); Bonney v. Tilley, ro9 Cal. 346, 42 Pac. 439 (1895). 
and later enforce them for face value, logical analysis based upon definitions of the fiduciary duty offers no satisfactory solution-or, at best, conflicting solutions. Nevertheless, there can be deduced from the cases certain factors that affect the outcome. If the corporation is closely or family owned; if the director does not disclose the opportunity to purchase the claims to the corporation; or if the corporation is actively in the market for the securities, whether or not it is financially able to purchase them, the courts tend to limit the officer or director to a recovery of the purchase price. If, on the other hand, he was seeking to preserve the corporation and did not purchase the claims merely for speculative purposes, there is good reason for allowing the officer or director to claim the face value of the securities. In the case of a company that is already in bankruptcy proceedings, the courts will not allow a director or officer to profit by his purchase. In the federal courts, technical insolvency at the time of purchase will not influence the decision unless there was an actual conflict of interest. Some courts, however, feel that a director should not be allowed to invest profitably in an insolvent corporation's obligations unless he can show a strong countervailing policy reason for so doing, such as an attempt to save the corporation from bankruptcy. 